\title{
ROLE OF MESOFAUNA ON LEAF LITTER DECOMPOSITION OF DENDROCALAMUS STRICTUS (ROXB.) NEES. AND SOIL CARBON SEQUESTRATION
}

\section{A. K. JHA ${ }^{1}$ AND A. M. KHURAD 2}

${ }^{1}$ Department of Zoology, Bhawabhuti Mahavidyalaya, Amgaon, Maharashtra, India

${ }^{2}$ Department of Zoology, RTM Nagpur University Campus, Nagpur, India

Corresponding author: knakj@rediffmail.com

\section{ABSTRACT:}

Litter decomposition is a useful biological indicator involving the interaction of vegetation, soil nutrient availability and soil organisms. The present study conducted under three different sites i.e. natural forest site, and two afforested sites of MOIL, and WCL to know the effect of different management plans on soil organic formation and nutrient release. Litter bag experiment was designed with leaf litter of Dendrocalamus strictus (Roxb.) Nees. and site specific soil mesofauna for a period of one year. Litter decay and carbon sequestration capacity of soil studied and periodical changes in organic carbon, nitrogen, phosphorus, potassium, Lignin, cellulose etc., were observed during the study period. The litter decay constant $\left(k_{l i t}\right.$ day $\left.^{-1}\right)$ was observed in natural forest, afforested coal mine site and afforested manganese mine site were 0.0012, 0.0012 and 0.0011 respectively. After one year, the leaf litter of Dendrocalamus strictus (Roxb.) Nees. observed with high $\mathrm{N}$ mineralization from 0.97 to $0.6 \% ; 0.9$ to $0.63 \%$ and 0.87 to $0.57 \%$ in MOIL, natural forest and WCL respectively. Present work concludes that the following important process to be considered for increasing soil carbon sequestration: (1) Input rates of organic matter (type of leaf litter), (2) Migration of soil organisms (type of soil fauna) (3) Rate of litter decomposition, (4) Rate of nutrient mineralisation, (5) Improvement of physico-chemical properties of mine restored soils. Hence, the development of productive forests on afforested mine lands could be converted into long-term sink for atmospheric carbon.

Key words: Soil mesofauna, litter decomposition, manganese mine, coal mine, soil carbon sequestration

\section{INTRODUCTION:}

Afforestation of mine sites is part of a realistic, low-cost, ecologically sound and sustainable reclamation strategy for bringing polluted sites into productive use (Dickinson, 2000). Litter decomposition is a useful biological indicator involving the interaction of vegetation, soil nutrient availability, micro and macro-fauna and microbial populations. Decomposition is a fundamental process of ecosystem 
functioning because it is a major determinant of nutrient cycling. The rate of plant decomposition and nutrient release are controlled by external factors such as climate and soil management, including rain fall, temperature, soil moisture and the nature of the plant material (Singh et al., 1999). Decomposition of soil organic matter is also controlled by some internal factors such as substrate quality and decomposer community structure.

"In general, low-nutrient species produce litter that is more difficult to decompose than litter from high-nutrient species (Berendse, 1994; Aerts and De Caluwe, 1997). Several environmental factors regulate the decomposition process i.e. humidity, temperature and edaphic factors (Pandey et al., 2006). Besides these, the leaf structure and their chemical constituents also play a significant role in this process. Soil fauna communities are known to improve soil structure by decreasing bulk density, increasing soil pore space, soil horizon mixing, increased aeration and drainage, increased water holding capacity, litter decomposition and improving soil aggregate structure (Abbott, 1989).

In healthy soil, invertebrates are abundant with adequate food supply and habitat requirements, soil fauna populations will thrive with minimal maintenance. Soil fauna include soil macrofauna (e.g. Oligochaeta, Diplopoda, Chilopoda and Isoptera etc.), mesofauna (e.g. Acari and Collembola etc.) and microfauna (e.g. Protozoa and Nematoda etc). Soil macrofauna are regarded as "engineer of ecosystem" by alteration of soil structure and availability.

The adult or the largest larval stage of soil biota having a body width of between 0.1 and $2 \mathrm{~mm}$ are termed mesofauna (Swift et al., 1979), and comprise groups such as the Enchytraeidae (pot worms) and the microarthropods, the latter group including both Collembola (springtails) and Acari (mites). It is well established that soil animals and their interactions with microorganisms play a primary role in the mineralisation of nutrients, and hence nutrient acquisition and the growth of plants (Coleman et al., 1983; Bardgett et al., 1999). Thus, changes in components of Earth's biodiversity not only cause concern for ethical and aesthetic reasons, but also because these changes are known to have the potential to alter ecosystem processes (Hooper et al., 2005). 
In the present study we focused to address the problem related to mine reclamation, in which we introduced site specific soil mesofauna with dominant leaf litter of Dendrocalamus strictus (Roxb.) Nees. Same study has been repeated in three different study sites i.e. natural forest site, and two afforested sites of MOIL, and WCL to know the effect of different management plans on soil organic formation and nutrient release.

\section{MATERIALS AND METHODS:}

\section{Study Area}

The experiment was conducted in natural forest site, Darekesa, Maharashtra, India and two afforested mine sites viz., Manganese Ore India Ltd. (MOIL), Gumgaon, Maharashtra, India and Western Coal Ltd. (WCL), Padmapur, Maharashtra, India. These experimental sites are situated at the geographic coordinates of $21^{\circ} 17^{\prime \prime}, 21^{02} 4^{\prime \prime}$ and $20^{\circ} 0^{\prime \prime} \mathrm{N}$ latitude, respectively and $80^{\circ} 34^{\prime \prime}, 78059^{\prime \prime}$ and $79^{\circ} 20^{\prime \prime} \mathrm{E}$ longitudes, respectively.

\section{Collection and identification of meso-fauna}

The soil fauna was extracted from a bulk sample of $10 \mathrm{~kg}$ undisturbed soil taken from site specific tree species of all three different land management's ( 3 sites X triplicate $=9$ samples). Samples were drawn by using a stainless steel corer (inner cross sectional diameter $8.5 \mathrm{sq} / \mathrm{c} . \mathrm{m})$ from a depth of $5 \mathrm{~cm}$. The soil samples were made free from macro fauna (i.e. earth worms, archinids, macro arthropods etc. were sieved out with the help of $2 \mathrm{~mm}$ sieve). This mesofauna rich soil sample was inoculated in micro-cosum of height: $15 \mathrm{~cm}$, diameter: $5 \mathrm{~cm}$ and followed by litter bag experiment. Extraction of soil samples were carried out by 'Expedition Funnel Apparatus' modified by Macfadyen (1953). 


\section{Litter bag experiment}

Ten grams of the air-dried leaf litter of Dendrocalamus strictus was placed within $15 \times 15 \mathrm{~cm}$ litter bags (mesh size $4 \mathrm{~mm}$ ). The open ends of the bags were tied with nylon rope, and the bags were buried in soil near the compost pits at a depth of $15 \mathrm{~cm}$. To mark the bags, wooden pegs were pushed into the ground close to the points where the bags were buried (Bernhard-Reversat, 1982). Treatments laid in nylon bags were sampled at intervals of $0,3,6,9$ and 12 months respectively to work out periodical changes in organic carbon, nitrogen, phosphorus, potassium, lignin, cellulose etc., and decomposition rates.

\section{Computation}

Organic matter decay, $\mathrm{N}$ and $\mathrm{P}$ mineralization constants for leaf litter were computed using negative exponential decay model of Olson (1963): X/X0. Exp(-kt), where $\mathrm{X}$ is the weight remaining at time $\mathrm{t}, \mathrm{XO}$ the initial weight, exp the base of natural logarithm, $\mathrm{k}$ the decay rate coefficient and the time (year). $\mathrm{N}$ and $\mathrm{P}$ mineralization constants $(\mathrm{kN}$ and $\mathrm{kP})$ were calculated by substituting dry weight with $\mathrm{N}$ and $\mathrm{P}$ contents in the foregoing formula (Singh and Shekhar, 1989). Further, the time required for $50 \%\left(\mathrm{t}_{1 / 2}\right)$ and $99 \%$ (t99) decay were calculated as $\mathrm{t}_{1 / 2}=0.0 .693 / \mathrm{k}$ and $\mathrm{t} 99=5 / \mathrm{k}$

\section{STATISTICAL ANALYSIS:}

In order to distinguish between different phases of weight-loss pattern during decomposition, multiple regressions / composite linear-regression model (Arunachalam et al., 1996) were used. The effect of climatic variables, initial litter chemistry and a few soil characteristics on the decomposition rate of leaf litter was assessed using simple linear regression function, $\mathrm{Y}=\mathrm{a}+\mathrm{bX}$. ANOVA with Dunnet Multivariate test. 


\section{RESULTS:}

\section{Soil analysis}

There was a large variation between the different depths of the soils in all three sites i.e. $0-15 \mathrm{~cm}, 15-30 \mathrm{~cm}$ and $30-45 \mathrm{~cm}$ respectively. The soil texture of three habitats was loamy sand. The bulk density of the forest soil was observed very low (1.0 to $1.36 \mathrm{~g} / \mathrm{CC}$ ), and in afforested mine sites it was observed with more i.e. 2.3 to 2.75 g/CC. High porosity and water holding capacity was observed in natural forest site and, it was very less recorded in both afforested mine sites. The $\mathrm{pH}$ of the soils was recorded in 7.1 to 8.1 range in all three studied sites. The organic carbon (OC), nitrogen $(\mathrm{N})$, phosphorous $(\mathrm{P})$ and potassium $(\mathrm{K})$ were found to be more in natural forest when compared to the afforested mine sites (Table-1).

\section{Mesofaunal distribution and density}

During the present study during July to June, 2009, different Collembolan extracted from sites belong to ten genera such as Xenylla, Isotomiella, Folsomides, Cryptopygus, Cyphoderus, Lepidocyrtus, Sinella, Entomobrya, Seira, and Sminthuridae. Other than the Collembolan population, several arthropods were also collected from the study are, Prostigmata, Mesostigmata, Cryptostigmata (Acarina), Diplura, Protura (belong to microarthropods), Coleoptera and other unidentified groups (belong to macroarthropods). Suborder Mesostigmata was dominant species of all studied sites and followed by Prostigmata, Coleoptera, and Cryptostigmata. Other groups of mesofauna population were extracted in negligible quantity.

The present study reports that the density of mesofauna was depend on the environmental conditions. The results of soil mesofaunal densities of all the three studied regions and five tree species are presented in fig- 1. Density of mesofauna was observed more in the month of July under Dendrocalamus strictus of MOIL site $(28 \pm 3$ of soil) whereas in natural forest, Darekasa and WCL maximum density was in the month of August (45 $\pm 5 / 100 \mathrm{~g}$ and $25 \pm 2 / 100 \mathrm{~g}$ of soil, respectively). In the rainy 
season i.e. July and August months, the density of meso-fauna was observed in maximum number.

\section{Decomposition of leaf litter}

In the litterbag experiment, various rates of mass loss were observed in different sites. Initially at the starting of the experiment (0 month), 10gm of litter was collected and kept it as 100\% foliar litter. The analysis remaining mass losses of litter bag were divided into 4 phases: $1^{\text {st }}, 2^{\text {nd }}, 3^{\text {rd }}$ and $4^{\text {th }}$ phases for the completion of $3,6,9$ and 12 months of the experiment respectively. In the first phase and last phase of the litter bag experiment very less foliar litter loss was observed. The percent of leaf litter decomposition of forest site, afforested coal mine site and afforested manganese mine site were depicted in fig- 2 .

\section{Nutrient release through litter decomposition}

Initial and final nutrient analysis of $\mathrm{N}, \mathrm{P}, \mathrm{K}$, carbon, lignin and cellulose were studied to know the role of nutrient release in litter decomposition. The initial nutrient analysis of Darekasa natural forest showed in Table-1. Initial litter nutrient analysis of afforested manganese mine site, Gumgaon and coal mine site, Padmapur were in line with natural forest litter. Very low percentage of initial cellulose content i.e. $9.67 \pm$ 1.53 was observed in manganese mine site, Gumgaon, however in both forest site, Darekasa and afforested coal mine site, Padmapur were more when compared to the natural forest site (Table-1). Initial Lignin percentage was observed more in natural forest, Darekasa (38 $\pm 1.86 \%)$ and followed by afforested WCL and MOIL site (29 $\pm 3 \%$ and $28 \pm \%)$ respectively. similar percentage in all studied sites $(28-38 \%)$.

\section{Decomposition dynamics of leaf litter}

The decay constant is a constant value $(\mathrm{k})$ to decompose leaf litter $\left(\boldsymbol{k}_{\text {Lit }}\right)$, nitrogen $\left(\boldsymbol{k}_{\boldsymbol{N}}\right)$, and phosphorus $\left(\boldsymbol{k}_{\boldsymbol{P}}\right)$ of natural forest, afforested coal mine site and afforested manganese mine site were given in table- 2. Dendrocalamus strictus showed similar decay constant of (0.0011- $0.0012 k_{\text {lit }}$ day $\left.^{-1}\right)$ in all studied sites. Decomposition constant for $50 \%$ decay $\left(\mathrm{t}_{1 / 2}\right)$ values of natural forest, afforested coal mine site and afforested manganese site are given in table-2. After a period of one year, the nutrients 
of litter, N, P, K, carbon, lignin and cellulose were decreased drastically (table-2). The Dendrocalamus strictus leaf litter showed very less $t_{1 / 2}$ and $t_{99}$ values, it means the observations of the present study predicts Dendrocalamus strictus leaf litter takes 578 - 630 days to decompose $50 \%$ ( $\mathrm{t}_{1 / 2}$ values), and 11.4 years to 12.5 years to decompose 99\% (t99 values).

\section{Carbon sequestration analysis}

Soil carbon sequestration in terms of conversion of atmospheric carbon $\left(\mathrm{CO}_{2}\right)$ into soil organic carbon (SOC) via leaf litter is a two step process. The present study reports that the amount of atmospheric carbon $\left(\mathrm{CO}_{2}\right)$ converted into organic carbon of leaf litter by photosynthesis (Organic carbon of leaf litter) in fig-3 under different soil management.

\section{DISCUSSION:}

Present study focuses on role of mesofauna on different land use managements with respect to natural forest, afforest MOIL site and afforested WCL site. The physicochemical and nutritional analysis of afforested mine sites (WCL and MOIL) have observed with low OC, N, P, and K values when compared with the natural forest site. The results of Yadav et al., (2010) confirmed the present physico-chemical characterstics of afforested soils. Many factors, such as poor physical texture, low water and nutrient holding capacity, deficiency of major nutrients (N, P, K), acidity and alkalinity, water supply, toxic metals, salinity, stability and surface temperature are the typical characters of mine sites (Cooke and Johnson, 2002).

The experiment was designed to represent typical conditions in the field with respect to mesofaunal composition and resource availability. The density observation of the present study showed that collembolan populations were declined from monsoon to summer. Moreover, the fauna abundance in both soil and litter is influenced by season, and not only the upper leaf layer as was shown by Argyropoulou et al. (1993). This is supported by previous studies showing that environmental conditions, especially moisture, play indirectly an important role in leaf litter decomposition by influencing microflora, meso-faunal activity, and certain invertebrate taxa like earthworms that are particularly sensitive to climatic changes 
(Haimi, 2000). In the present study, the fauna shows a seasonal vertical migration as reflected by movement of fauna up from the soil into the leaf litter during the wet season, and down again during the dry season. Vertical movement was previously described in isopods burrowing during summer in the desert and during winter in mesic habitats (Warburg, 1993). In the present study we found that meso-fauna are abundant in July and August (rainy) followed by winter and then summer in the leaf litter of all studied sites, this is strongly significant correlation with climatic and micro-climatic conditions.

Changes in climate and litter chemistry are the major factors govern the rate of organic matter decomposition by meso-fauna at the continental and global scales (Aerts, 1997). In the study, maximum litter decomposition was observed in the $2^{\text {nd }}$ phase i.e. Oct-Dec (Fig. 1). The rapid rate of decay in this phase was the net effect of a large number of processes such as utilization of readily available energy sources by microbes, loss of water-soluble components and non-structural carbohydrates from the leaf litter (Bloomfield et al., 1993), and removal of litter particles by soil mesofauna (Swift et al., 1979). Initial decomposition takes much time because of breakdown of lignin and cellulose. Greater weight loss during the $2^{\text {nd }}$ phase may be due to high percentage soil moisture and soil temperature, and also due to leaching of water-soluble substances from the litter mass. Smaller weight loss during $3^{\text {rd }}$ phase might be due to cool and dry conditions. This is obvious from the positive correlation between the rate of weight loss with soil moisture and rainfall (Moretto et al., 2001; Austin and Vitousek, 2000). Final phase (4th phase) is very slow in all studied sites and in all studied litter species. A decline in the decomposition rate after the rapid phase of decay may be attributed to higher percentage of recalcitrant fractions like cellulose, lignin and tannin during the advanced stage of leaf decay. These substances are known to control decay rate by showing resistance to enzymatic attack and by physically interfering with the degradation of other chemical fractions of the cell wall (Bloomfield et al., 1993). The meso-fauna, such as Cyphoderus, Lepidocyrtus, Entomobrya, Xenylla (the most abundant group in Collembola) are important litter fragmenters or detrivors (Adl, 2003). The absence or reduction of these invertebrates in the afforested mine site might be responsible for the slow decomposition. 
After one year, the leaf litter of Dendrocalamus strictus observed with high $\mathrm{N}$ mineralization from 0.97 to $0.6 \%$; 0.9 to $0.0 .63 \%$ and 0.67 to $0.5 \%$ in MOIL, natural forest and WCL respectively. It is observed that the densities of meso-faunal communities are responsible for $\mathrm{N}$ mineralization. The microcosm study by Seeber et al (2006) showed that a complete community of microarthropods (collembolans and mites) can enhance net $\mathrm{N}$ mineralisation at dry, mesic and moist conditions also in the absence of enchytraeids. Collembola and enchytraeids augmented parts of the acid soluble carbon pool, probably by tethering organic compounds to mineral particles in their gut and by releasing organomineral complexes in their faeces (Koutika et al., 2001).

The introduced soil fauna effectively degraded the most recalcitrant carbon (insoluble pools) and transferred labile carbon into more stable pools. Several litter decomposition studies have been conducted at the large spatial scales on leaf litter (Aerts, 1997; Dyer et al., 1990; Meentemeyer, 1978; Swift et al., 1979), woody debris (Yin, 1999) and root litter (Silver and Miya, 2001). These results indicated a huge variation between the type of litter and their decomposition rates day-1 year $^{-1}\left(\mathrm{k}_{\mathrm{Lit}}\right.$ values). SOC rates of the present work proved that the afforested mine sites have quite better soil carbon sequestration rates than the natural forest.

\section{CONCLUSION:}

The present work contains results of an ecological study involving subterranean Collembolan and different soil factors and their influence on soil biological processes, nutrient cycling, soil structure as well as impact of soil parameters on the population structure of mesofauna from two afforested mine sites viz., Manganese Ore India Ltd. (MOIL), Gumgaon, Maharashtra, India and Western Coal Ltd. (WCL), Padmapur, Maharashtra, India and a forest site, Darekesa, Maharashtra, India. There are many factors and processes that determine the direction and rate of change in soil carbon sequestration content when soil management practices are changed. Present work concludes that the following important process to be considered for increasing soil carbon sequestration: (1) Input rates of organic matter (type of leaf litter), (2) Migration of soil organisms (type of soil fauna) (3) Rate of litter decomposition, (4) Rate of nutrient mineralisation, (5) Improvement of Physico-chemical properties of mine 
restored soils. The development of productive forests on afforested mine lands could be converted into long-term sink for atmospheric carbon. Land that has been mined for coal/ manganese contributes to atmospheric carbon via land use change.

\section{ACKNOWLEDGEMENTS:}

Authors are thankful to Dr. S. M. Buskute, Principal, Bhawabhuti Mahavidyalaya, Amgaon, Maharashtra for providing laboratory and other facilities. We are also grateful to Dr. G. Phani Kumar, Scientist, DFRL, Mysore for sharing technical information. The paper forms the part of the thesis submitted by the first author for the award of Doctoral degree in Science (Zoology). The research product was funded by University Grants Commission, WRO, Pune (F. No: 47-185/07) and physically supported by the Bhawabhuti Mahavidyalaya, Amgaon.

Table: 1. Initial and final nutrient composition of litter in natural forest, afforested MOIL, WCL sites

\begin{tabular}{|l|l|l|l|l|l|l|}
\hline & \multicolumn{3}{|c|}{ Initial } & \multicolumn{1}{c|}{ Final } \\
\cline { 2 - 7 } & Natural forest & \multicolumn{1}{|c|}{ MOIL } & \multicolumn{1}{|c|}{ WCL } & Natural forest & \multicolumn{1}{c|}{ MOIL } & \multicolumn{1}{c|}{ WCL } \\
\hline $\begin{array}{l}(\mathrm{N}) \\
\%\end{array}$ & $0.9 \pm 0.02$ & $\begin{array}{l}0.97 \pm \\
0.09\end{array}$ & $\begin{array}{l}0.67 \pm \\
0.01\end{array}$ & $0.63 \pm 0.009$ & $0.6 \pm 0.009$ & $0.5 \pm 0.04$ \\
\hline & & $0.08 \pm$ & & & & $0.075 \pm$ \\
P) \% & $0.09 \pm 0.002$ & 0.004 & $0.1 \pm 0.01$ & $0.03 \pm 0.001$ & $0.065 \pm 0.003$ & 0.004 \\
\hline K) \% & $1.2 \pm 0.03$ & $1 \pm 0.01$ & $1.1 \pm 0.01$ & $0.24 \pm 0.003$ & $0.18 \pm 0.05$ & $0.198 \pm 0.01$ \\
\hline OC & & $41 \pm 2.1$ & $44 \pm 5.5$ & $14 \pm 1.2$ & $16.5 \pm 1.5$ & $14 \pm 1.6$ \\
$\%$ & $42 \pm 2$ & $28 \pm 2$ & $29 \pm 3.00$ & $28 \pm 1.1$ & $23 \pm 1.2$ & $24 \pm 3$ \\
\hline L \% & $38 \pm 1.86$ & $9.67 \pm$ & $11.67 \pm$ & & & $11.67 \pm$ \\
\hline Cel & & 1.53 & 2.08 & $7.67 \pm 2.52$ & $9.67 \pm 1.73$ & 2.08 \\
\hline C:N & $46.33 \pm 1.53$ & $53.2 \pm 9$ & $65.7 \pm 9.4$ & $22.2 \pm 2.8$ & $26.7 \pm 3.2$ & $28.0 \pm 1.9$ \\
\hline & & $36.36 \pm$ & $43.28 \pm$ & & & \\
L:N & $42.22 \pm 2.775$ & 4.62 & 2.30 & $44 . \pm 2.45$ & $38.33 \pm 1.66$ & $48.00 \pm 2$ \\
\hline & & $0.63 \pm$ & $0.58 \pm$ & & & $0.67 \pm$ \\
LCI & $0.62 \pm 0.045$ & 0.04 & 0.041 & $33.08 \pm 3.075$ & $0.66 \pm 0.041$ & 0.015 \\
\hline
\end{tabular}


International Journal of Researches in

September 2013

ISSN No. (Online):

Biosciences, Agriculture \& Technology

Issue-1, Volume-1

Table: 2. Litter decay and nutrient mineralization constants of all studied sites ( $k$ day $^{-1}$ )

\begin{tabular}{|l|c|c|c|c|c|}
\hline & $\boldsymbol{k}_{\mathbf{L i t}}$ & $\boldsymbol{k}_{\boldsymbol{N}}$ & $\boldsymbol{k}_{\boldsymbol{P}}$ & $\mathbf{t}_{\mathbf{1 / 2}}$ (days) & $\mathbf{T}_{\mathbf{9 9}}$ (years) \\
\hline Natural forest & 0.0012 & 0.0010 & 0.0024 & 578 & 11.4 \\
\hline Afforested WCL site & 0.0011 & 0.0008 & 0.0008 & 630 & 12.5 \\
\hline Afforested MOIL site & 0.0012 & 0.0007 & 0.0006 & 578 & 11.4 \\
\hline
\end{tabular}

Note: $\boldsymbol{k}_{\boldsymbol{L} i t}-$ Litter decay constant, $\boldsymbol{k}_{\boldsymbol{N}}$ - Nitrogen mineralization constant, $\boldsymbol{k}_{\boldsymbol{P}}-$ Phosphorus mineralization constant.

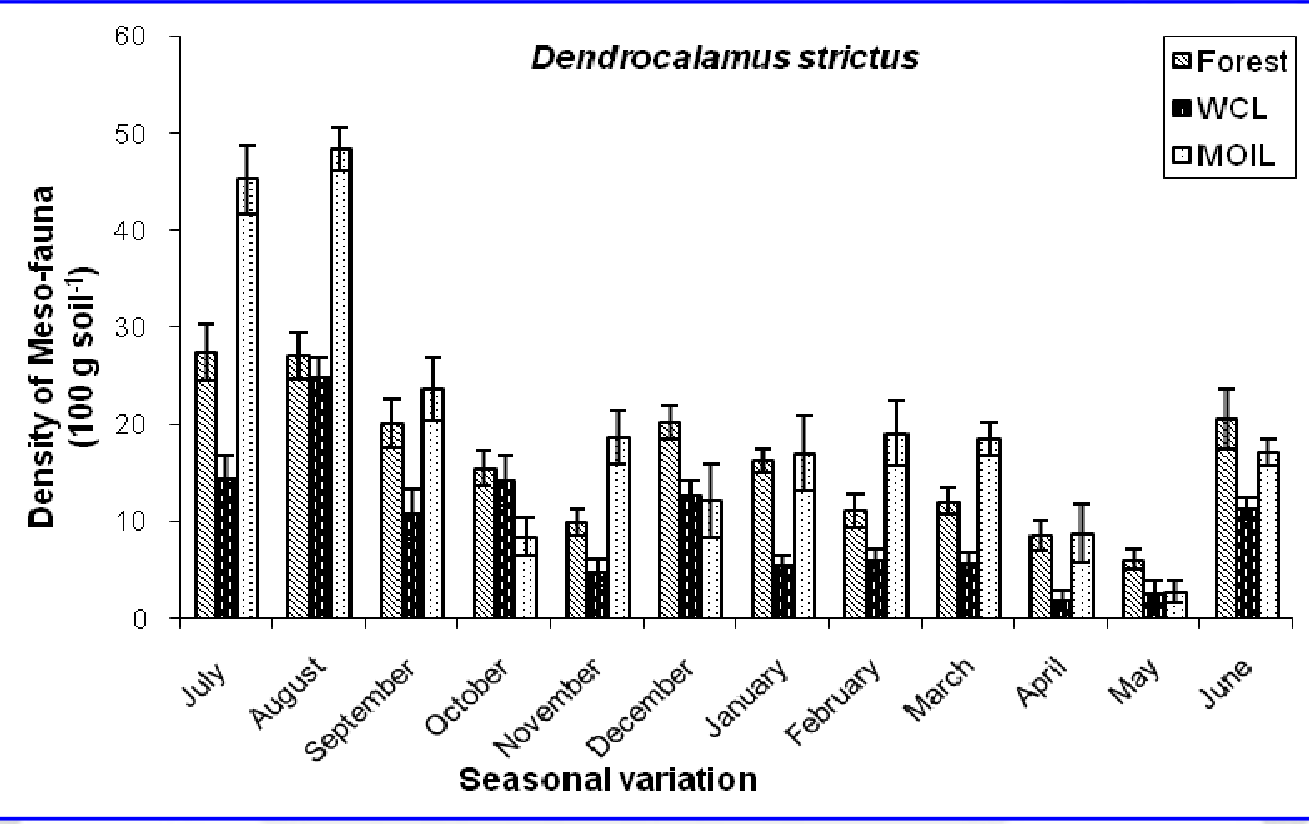


International Journal of Researches in Biosciences, Agriculture \& Technology
September 2013

Issue-1, Volume-1
ISSN No. (Online): 2347-517X

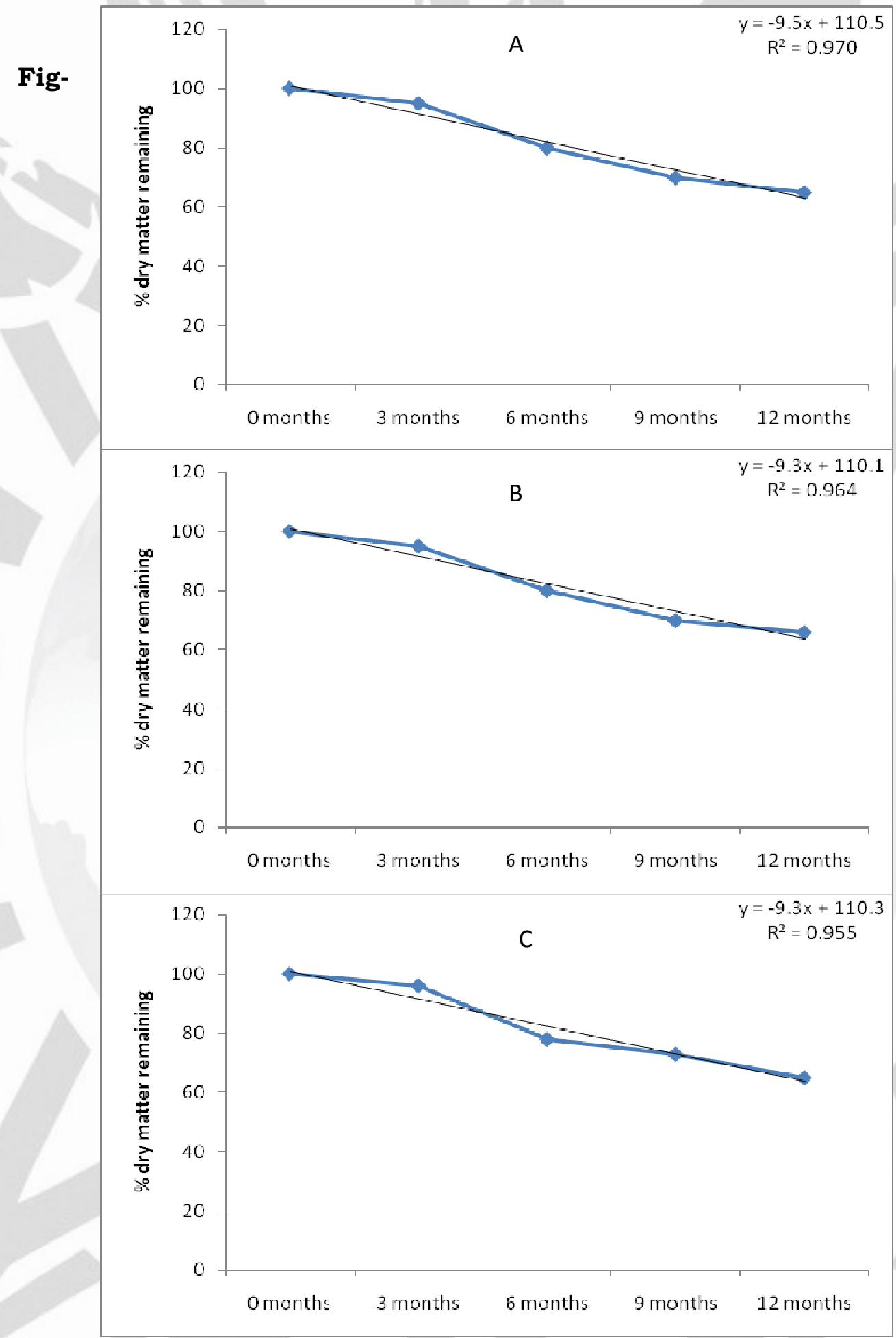

1:

Seasonal variation of meso-fauna densities $(100 \mathrm{~g}$ soil-1) in Dendrocalamus strictus plantations of studied sites 
Fig:2 Leaf litter decomposition of Dendrocalamus strictus in (A) Natural forest site, (B) Afforested coal mine site and (C) Afforested manganese mine site.

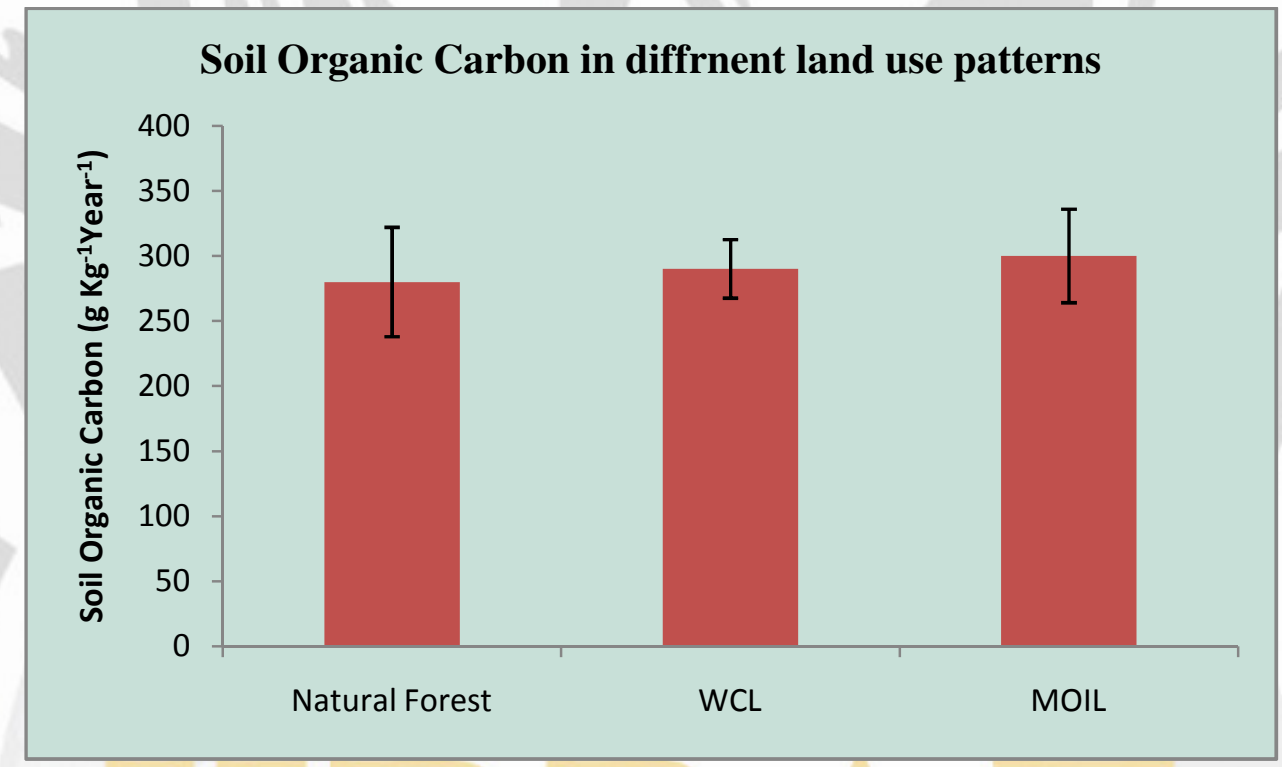

Fig:3 Soil Carbon Sequestration by mesofaunal litter decomposition of Dendrocalamus strictus.

\section{REFERENCES:}

Abbott, I. (1989): The influence of fauna on soil structure. In : Majer, J. D., (Ed.), Animals in Primary Succession : The Role of Fauna in Reclaimed Lands, Cambridge University Press, City, : Pp.39-50.

Adl, S. M. (2003): The Ecology of Soil Decomposition, CABI, Wallingford.

Aerts, R. and De Caluwe, H., (1997): Initial litter respiration rates as indicator for longterm leaf litter decomposability of Carex species, Oikos, 80 : Pp.353-361.

Aerts, R. (1997): Climate, leaf litter chemistry and leaf litter decomposition in terrestrial ecosystems: a triangular relationship, Oikos, 79 : Pp.439-449.

Argyropoulou, M. D., Asikidis, M. D., Iatrou, G. D. and Stamou, G. P. (1993): Colonization patterns of decomposing litter in a maquis ecosystem, European Journal of Soil Biology, 29(2) : Pp.183-191. 
Arunachalam, A., Pandey, H. N., Tripathi, R. S. and Maithani, K. (1996): Fine root decomposition and nutrient mineralization patterns in a subtropical humid forest following tree cutting, For. Ecol. Manag., 86 : Pp.141-150.

Austin, A. T. and Vitousek, P. M. (2000): Precipitation, decomposition and litter decomposability of Metrosideros polymorpha in active forests on Hawaii, Journal of Ecology, 88 : Pp.129-138.

Bardgett, R. D., Mawdsley, J. L., Edwards, S., Hobbs P. J., Rodwell, J. S. and Davies, W. J. (1999): Plant species and nitrogen effects on soil biological properties of temperate upland grasslands, Functional Ecology, 13 : Pp.650-660.

Berendse, F. (1994): Litter decomposability : a neglected component of plant fitness, Journal of Ecology, 82 : Pp.187-190.

Bernhard-Reversat, F. (1982): Measuring litter decomposition in a tropical forest ecosystem : comparison of some methods, Int. J. Ecol. Environ. Sci., 8 : Pp.6371.

Bloomfield, J., Vogt, K. A. and Vogt, D. J. (1993): Decay rate and substrate quality of fine roots and foliage of two tropical tree species in Luquillo Experimental forest, Puerto Rico, Plant and Soil, 150 : Pp.233-245.

Coleman, D. C., Reid, C. P. P. and Cole, C. V. (1983): Biological strategies of nutrient cycling in soil ecosystems, Advances in Ecological Research, 13 : Pp.1-55.

Cooke, J. A. and Johnson, M. S. (2002): Ecological restoration of land with particular reference to the mining of metals and industrial minerals : A review of theory and practice, Environ. Rev., 10 : Pp.41-71.

Dickinson, N. M. (2000): Strategies for sustainable woodland on contaminated soils, Chemosphere, 41 : 259- 263. doi:10.1016/S0045-6535(99)00419-1.

Dyer, M. L., Meentemeyer, V. and Berg, B. (1990): Apparent controls of mass loss rate of leaf litter on a regional scale : litter quality versus climate, Scand J Fort Res, 5 : Pp.311-24.

Haimi, J. (2000): Decomposer animals and bioremediation of soils, Environmental Pollution, 107 : Pp.233-238. 
Hooper, D. U., Chapin, F. S. III, Ewel, J. J., Hector, A., Inchausti, P. and Lavorel, S. (2005): Effects of biodiversity on ecosystem functioning : a consensus of current knowledge, Ecol. Monogr., 75, Pp.3-35.

Koutika, L. S, Hauser, S. and Henrot, J. (2001): Soil organic matter in natural regrowth, Pueraria phaseoloides and Mucuna pruriens fallow, Soil Biology \& Biochemistry, 33 : Pp.1095-1101.

Meentemeyer, V. (1978): Macroclimate and lignin control of litter decomposition rates, Ecology, 59 : Pp.465-72.

Moretto, A. S., Distel, R. A. and Didoné, N. G. (2001): Decomposition and nutrient dynamic of leaf litter and roots from palatable and unpalatable grasses in semiarid grassland, Applied Soil Ecology, 18 : Pp.31-37.

Pandey, C. B., Sharma, D. K. and Bargali, S. S. (2006): Decomposition and nitrogen release from Leucaena leucocephala in central India, Tropical Ecology 47(1) : Pp.149-151.

Seeber, J., Scheu, S. and Meyer, E. (2006): Effects of macro-decomposers on litter decomposition and soil properties in alpine pastureland : A mesocosm experiment, Applied Soil Ecology, 34 (2-3) : Pp.168-175.

Silver, W. L. and Miya, R. K. (2001): Global patterns in root decomposition: comparisons of climate and litter quality effects, Oecologia,129 : Pp.407-419.

Singh, K. P., Shekhar, C. (1989): Concentration and release pattern of nutrients (N, P, $\mathrm{K})$ during decomposition of maize and wheat roots in a seasonally dry tropical region, Soil Biol. Biochem., 21, Pp.81 - 85.

Singh, K. P., Singh, P. K. and Tripathi, S. K. (1999): Litter fall, litter decomposition and nutrient release patterns in four native tree species raised on coal mine spoil at Singrauli, India, Biology and Fertility of Soils, 29 : Pp.371-378.

Swift, M. J., Heal, O. W. and Anderson, J. M. (1979): Decomposition in Terrestrial Ecosystem, University of California Press, Berkeley, CA.

Warburg, M. R. (1993): Evolutionary biology of land isopods, Springer Verlag, Heidelberg, Germany, : Pp.159. 
Yadav, S. K., Dhote, M., Kumar, G. P., Sharma, J., Chakrabartia, T. and Juwarkar, A. A. (2010): Differential antioxidative enzyme responses of Jatropha curcas L. to chromium Stress, Journal of Hazardous Materials, 180 : Pp.609-615.

Yin, X. (1999): The decay of forest woody debris : numerical modeling and implications based on some 300 data cases from North America Oecologica,121 : Pp.81-98. 